\title{
ARTICLE
}

\section{Embryonic and larval development of Dissostichus eleginoides (Pisces: Nototheniidae)}

\author{
Desarrollo embrionario y larval de Dissostichus eleginoides (Pisces: Nototheniidae)
}

\author{
Armando Mujica ${ }^{1}$, Daniela Peñailillo ${ }^{1}$, Alberto Reyes $^{2}$ and María Luisa Nava ${ }^{1}$ \\ Departamento de Acuicultura, Universidad Católica del Norte, P.O. Box 117, Coquimbo, Chile. amujica@ucn.cl \\ ${ }^{2}$ Corporación de Educación La Araucana, Puerto Montt, Chile
}

\begin{abstract}
Resumen.- El desarrollo embrionario y larval de Dissostichus eleginoides es descrito por primera vez utilizando ejemplares cultivados en laboratorio $\left(4\right.$ a $\left.8^{\circ} \mathrm{C}\right)$. Periódicamente fueron fijados huevos y larvas para describir el desarrollo. Los huevos midieron de 3,1 a 3,5 mm de diámetro, esféricos, de corion transparente y superficie levemente rugosa, con 28 gotas oleosas, ubicadas en torno al polo germinativo y tardaron 30 a 33 días en eclosionar. Las larvas consumieron el saco vitelino en 18 días (larvas vitelogénicas, 8-13 mm), luego comienzan a desarrollarse los rayos de las aletas, se incrementa la pigmentación y se distinguen 3 zonas con agregación de melanóforos (parte posterodorsal de la cabeza, sobre el intestino y delante del pedúnculo caudal). El complejo hipural a estuvo completamente formado cuando las larvas midieron entre 49 y $53 \mathrm{~mm}$ (LS), lo que ocurrió a 57 días de la eclosión.
\end{abstract}

Palabras clave: Dissostichus eleginoides, desarrollo embrionario y larval

\begin{abstract}
This is the first description of the embryonic and early larval development of laboratory-reared (4- $\left.8^{\circ} \mathrm{C}\right)$ Dissostichus eleginoides. Specimens were periodically sampled to describe egg and larval development. Eggs were spherical (3.1-3.5 mm diameter) and had a transparent chorion and slightly rough surface, with 28 oil globules located around the germinal pole. Eggs incubated between 30 and 33 days until hatching. At day 18 post-hatching, the yolk sac was absorbed by vitellogenic larvae (8-13 $\mathrm{mm}$ total length), after which, the fin rays started to develop, pigmentation increased, and main melanophore aggregation zones were distinguished on the posterodorsal part of the head, the intestine, and before the caudal peduncle. The hypural complex was fully formed by day 57 post-hatching ( $49-53 \mathrm{~mm}$ standard length).
\end{abstract}

Key words: Dissostichus eleginoides, embryonic and larval development

\section{INTRODUCTION}

Dissostichus eleginoides Smitt, 1898 (Patagonian toothfish) is distributed in deep sub-Antarctic waters along the Antarctic Polar Front, extending north to $35^{\circ} \mathrm{S}$ on the Patagonian Shelf in the Atlantic Ocean (Collins et al. 2010). This species is a commercial resource in Chilean industrial and artisan fishery industries, with exploitation determined by an annual global catch quota (SUBPESCA 2010). Commercial interest in the Patagonian toothfish, which is also known as the dusky grouper, black hake, and Chilean seabass, began in the 1970s as a result of high prices and domestic and international market demands (Reyes et al. 2012). Information on this species is restricted to annual reports submitted by the Servicio Nacional de Pesca y Acuicultura (SERNAPESCA) of Chile (Arana et al. 1994).

Dissostichus eleginoides is a sexually dimorphic dioecious species that can inhabit down to depth of $2500 \mathrm{~m}$. During ontogenesis, $D$. eleginoides progressively migrates to deeper waters (Collins et al. 2010). Few data have been reported for the early life stages of this species. Eggs are released in deep waters and, due to their positive buoyancy, can be collected in the upper $500 \mathrm{~m}$ of the water column (Evseenko et al. 1995).
Larvae hatch between October and December and remain in the upper water column until metamorphosis (Collins et al. 2010).

This study was carried out by Corporación de Educación La Araucana (CELA) within the framework of FONDEF project DA09I1003, 'Farming Development of Patagonian Toothfish (Dissostichus eleginoides)'. The embryonic and larval development of $D$. eleginoides was observed and described with the aim of contributing to the knowledge of early life history traits of this species, which could be used for aquaculture purposes.

\section{MATERIALS AND METHODS}

To observe the embryonic and larval development of Dissostichus eleginoides, eggs were obtained from an experimental farm administered by the Corporación de Educación La Araucana located in Puerto Montt, Los Lagos Region, Chile. Specifically, eggs were collected from spawning (December 2012) females ranging from 94 to $98 \mathrm{~cm}$ in total length (TL). 
Five to 10 eggs were sampled daily to assess developmental progress from fertilization to hatching. These eggs were stored in a formaldehyde (5\%) and seawater solution. Similarly, larvae were periodically sampled at the end of embryonic development. The collected larvae were gradually anesthetized with AQUI'S to prevent contractions and were stored in a formaldehyde and $5 \%$ seawater solution. During both egg and larvae development, seawater temperature was maintained at $6 \pm 2^{\circ} \mathrm{C}$.

The eggs and larvae were observed using optical and stereomicroscopes equipped with a camera lucida. The meristic and morphometric characteristics of the different developmental stages were measured and described according to traditional methodology for the study of ichthyoplankton (Ciechomsky 1981).

\section{RESULTS}

\section{EMBRYONIC DEVELOPMENT}

At fertilization, the eggs were spherical (3.1-3.5 mm diameter) and presented a transparent chorion, a slightly rough surface, and a small perivitelline space.

Cell division began at fertilization and ended after 4 days, culminating with gastrulation (Figs. 1a-f). Afterwards, germination was distinguishable, as were the vegetative pole and the formation of essential embryo layers (i.e. ectoderm, mesoderm, and endoderm), as evidenced by visualizing the germ ring. Seven days after fertilization, a formed embryo ( $2 \mathrm{~mm}$ TL) and 28 oil globules situated around the germinating pole $(\phi=1.1 \mathrm{~mm})$ (Fig. 2a).

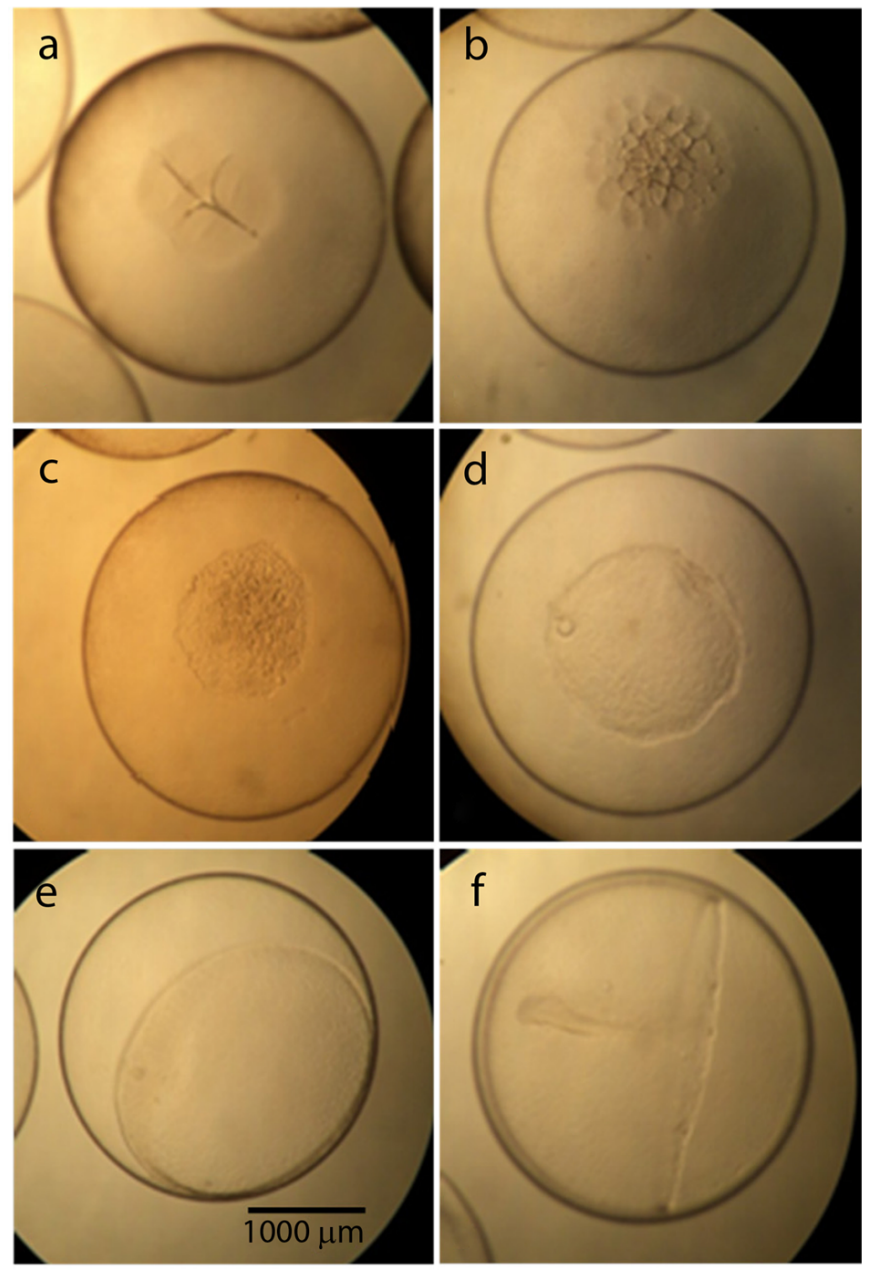

Figure 1. Morphology of Dissostichus eleginoides (Patagonian toothfish) embryos. a) day 0 (fertilization), b) day 1, c) day 3, d) day 4, e) day 5, and f) day 6 / Morfología de embriones de Dissostichus eleginoides (bacalao de profundidad). a) día 0 (fecundación), b) día 1, c) día 3, d) día 4, e) día 5 y f) día 6 
Ten days after fertilization, the anterior (cephalic) and posterior (caudal) sections of the embryo (2.9 $\mathrm{mm} \mathrm{TL})$ were distinguishable (Fig. 2b). Numerous stellate melanophores were also visible on the lateral sides of the embryo.

Eleven days after fertilization, the embryo protruded from the vitelline mass, with the cephalic portion wider than the body. The optical cameras were well defined, and stellate melanophores were distinguished along the entire body. Near the head, melanophores and 7 oil globules of varying sizes were observed on lateral sides of the embryo.

Thirteen days after fertilization, the embryo was partially separated from the yolk, but was attached along the head to the anus $(1.8 \mathrm{~mm})$. The optical cameras were fully formed and prominent in the cephalic portion (Fig. 2c). Fifteen oil globules were present in the yolk mass, and the melanophores persisted on the lateral sides of the embryo.
Fifteen days after fertilization, the embryo remained attached to the yolk from the opercular sector to the anus $(\approx 2 \mathrm{~mm})$. Evident melanophores were displayed on the side edges of the body. The length from the anus to the distal end of the body was $1.5 \mathrm{~mm}$. At the anterior end of the embryo, a slight pigmentation encircled the area for the mouth.

Seventeen days after fertilization, the embryo was larger and presented an embryonic dorsal fin fold. The length of body attached to the yolk sac was $2.4 \mathrm{~mm}$ (Fig. 2d). The eye crystalline presented slight pigmentation. The stellate melanophores on the side edges of the body were discontinuous, and melanophores were located in the cephalic and ventral areas and in front of the caudal peduncle.
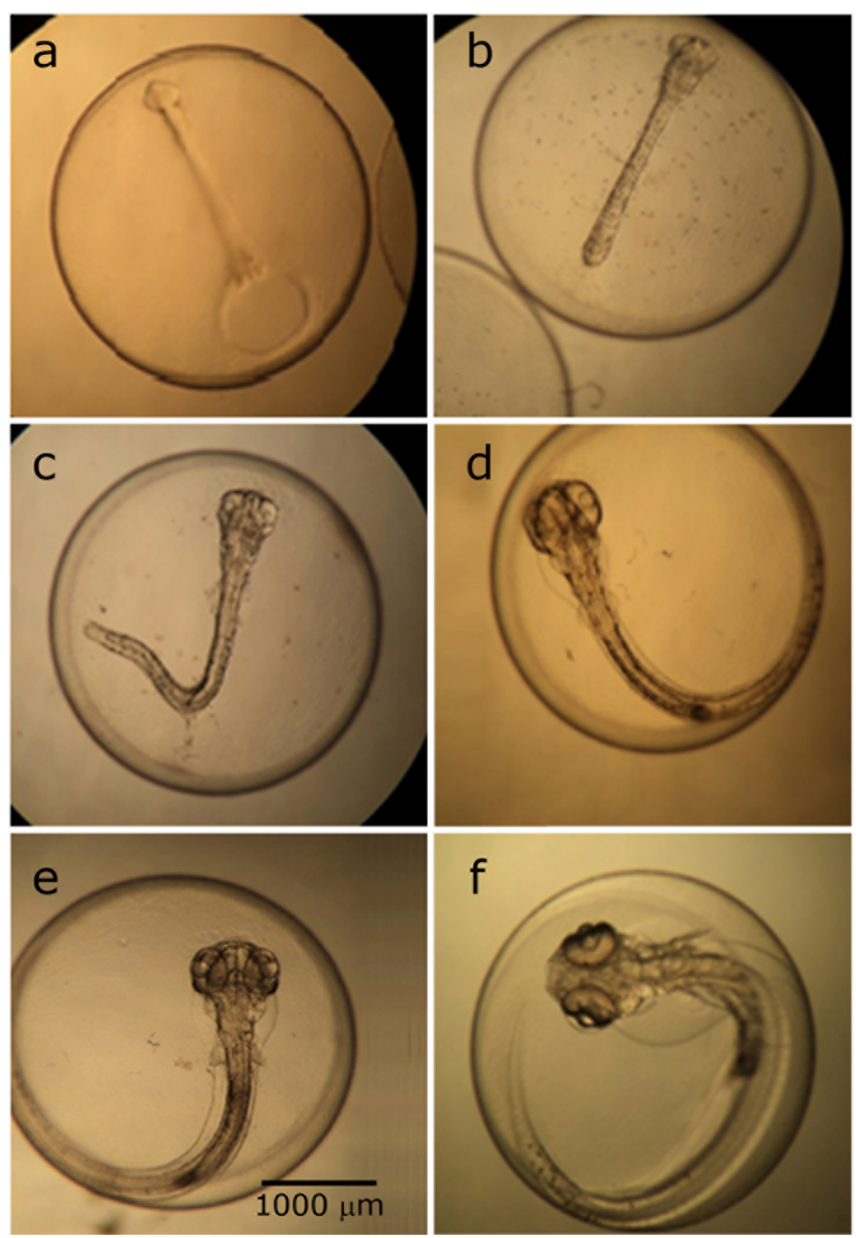

Figure 2. Morphology of Dissostichus eleginoides (Patagonian toothfish) embryos. a) day 7, b) day 10, c) day 13, d) day 17, e) day 19, and f) day 24 / Morfología de embriones de Dissostichus eleginoides (bacalao de profundidad). a) día 7, b) día 10, c) día 13, d) día 17, e) día 19 y f) día 24 
Nineteen days after fertilization, the crystalline was fully pigmented, and the optical lenses (cornea skin) completely covered the eye. At this point, embryo size exceeded twice the egg diameter (Fig. 2e).

Twenty-four days after fertilization, the eyes measured $\approx 500$ $\mu \mathrm{m}$ in diameter. The embryonic fin was fully developed; 11 melanophores were located in the anterior part of the head, and the oral structures began to develop. Ventrolateral melanophores were distinguished in the post-anal region and in front of the caudal peduncle (Fig. 2f). The eggs hatched between 30 and 33 days post-fertilization.

\section{LARVAL DEVELOPMENT}

The newly hatched larvae (1-3 days) were long and thin (8.5 \pm $0.2 \mathrm{~mm} \mathrm{TL}$ ). The yolk sac was prominent ( $2.7 \mathrm{~mm} \times 1.2 \mathrm{~mm})$, and the digestive tract was located in the distal section of the larva. The embryonic fin extended dorsally from the head to the distal end and ventrally from this to the anus. Scattered melanophores were present in the dorsal region of the head, whereas groups of band-forming melanophores were located on the digestive tract and before the caudal peduncle (Fig. 3a). The eyes were round and of equal diameter in the more developed embryos. The mouth was fully formed but not functional.

In the first 18 days post-hatching, the larvae were lecithotrophic. Larval morphology did not change, but body length progressively increased while yolk sac volume progressively decreased.

Fifteen days after hatching, larvae were $9.7 \pm 0.2 \mathrm{~mm}$ TL. The yolk sac was almost entirely absorbed and was covered by an increased number of melanophores, which also evidenced increased size. At this stage of development, pectoral fin rays began to form. Caudal fin rays, which later gave rise to the hypural complex, were forming in the ventral part of the distal end of the notochord (Fig. 3b).

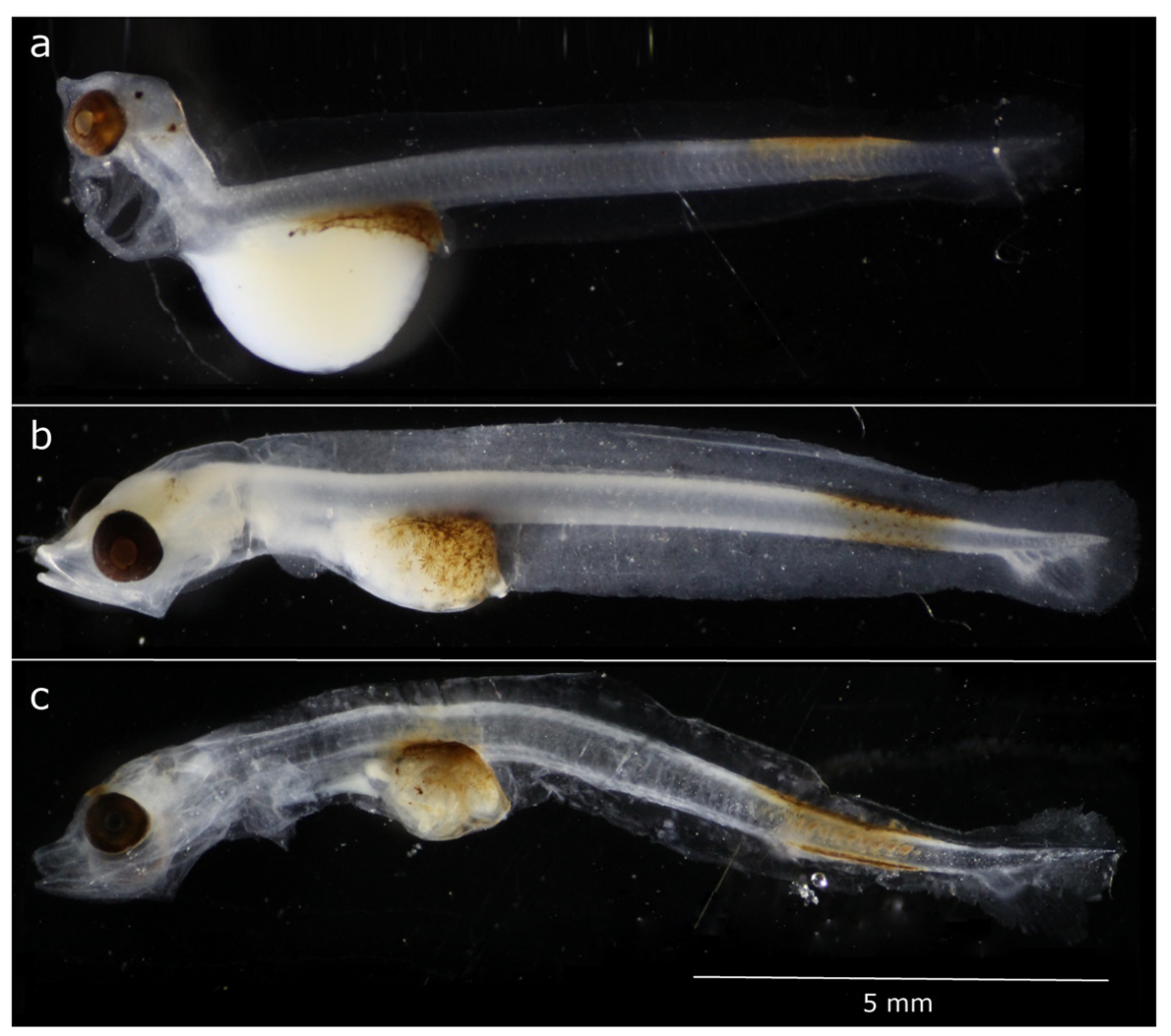

Figure 3. Lateral view of Dissostichus eleginoides (Patagonian toothfish) larvae. a) 3 days post-hatching, b) 15 days posthatching, c) $\mathbf{1 8}$ days post-hatching / Vista lateral de larvas de Dissostichus eleginoides (bacalao de profundidad). a) a 3 días de la eclosión, b) a 15 días de la eclosión, c) a 18 días de la eclosión 
Eighteen days after hatching, the larvae were more robust $(13.0 \pm 2.0 \mathrm{~mm} \mathrm{TL})$ and had $46 \pm 2$ myomeres. At this stage, notochord flexion began; the yolk sac was completely absorbed, and the mouth was functional. The distribution pattern of pigmentation did not change (Fig. 3c).

Twenty-six days after hatching, the larvae were larger (16.0 $\pm 2.0 \mathrm{~mm}$ TL). Pectoral ( $21 \pm 1$ rays) and caudal fin rays (11 \pm 1 rays) were distinguished. The eyes $(\phi=1.0 \pm 0.2 \mathrm{~mm})$ were prominent, and the melanophores (10-15) of the cephalic area were visibly larger. A line of melanophores was present in the distal margin of the operculum (Fig. 4a).

Forty-four days after hatching, the larvae measured $39.0 \pm$ $2.0 \mathrm{~mm}$ (TL) and exhibited the same melanophore distribution pattern as previously observed. Dorsal, anal, pectoral, and caudal fin rays numbered respectively $20 \pm 1,25 \pm 1,22 \pm 1$, and $15 \pm 1$ (Fig. 4 b). Dorsal $\left(45^{\circ}\right)$ notochord development was observed.

Fifty-seven days after hatching, the larvae measured 51.0 \pm $2.0 \mathrm{~mm}$ (TL). The number of rays for all fins was unchanged.
The number of melanophores increased in the cephalic region and in the area around the mouth. At the base of each dorsal fin ray, there was a melanophore on each side, forming a dorsolateral line (Fig. 4c).

\section{Discussion}

Previous studies describing the morphology D. eleginoides embryos and larvae were based on wild specimens, while the present study is the first to describe the early life ontogeny of D. eleginoides specimens reared under controlled laboratory conditions.

The overall morphological characteristics of eggs, such as the rugged and transparent chorion, matched well with descriptions in previous studies, but the size of the laboratoryreared eggs (3.1-3.5 mm) was notably less than wild eggs (4.34.7 mm) (Kellermann 1990, Koubbi et al. 1990, Evseenko et al. 1995). This difference could be partially due to the different sampling areas for laboratory and wild eggs in the Antarctic Ocean (South Georgia and Kerguelen Islands, respectively).
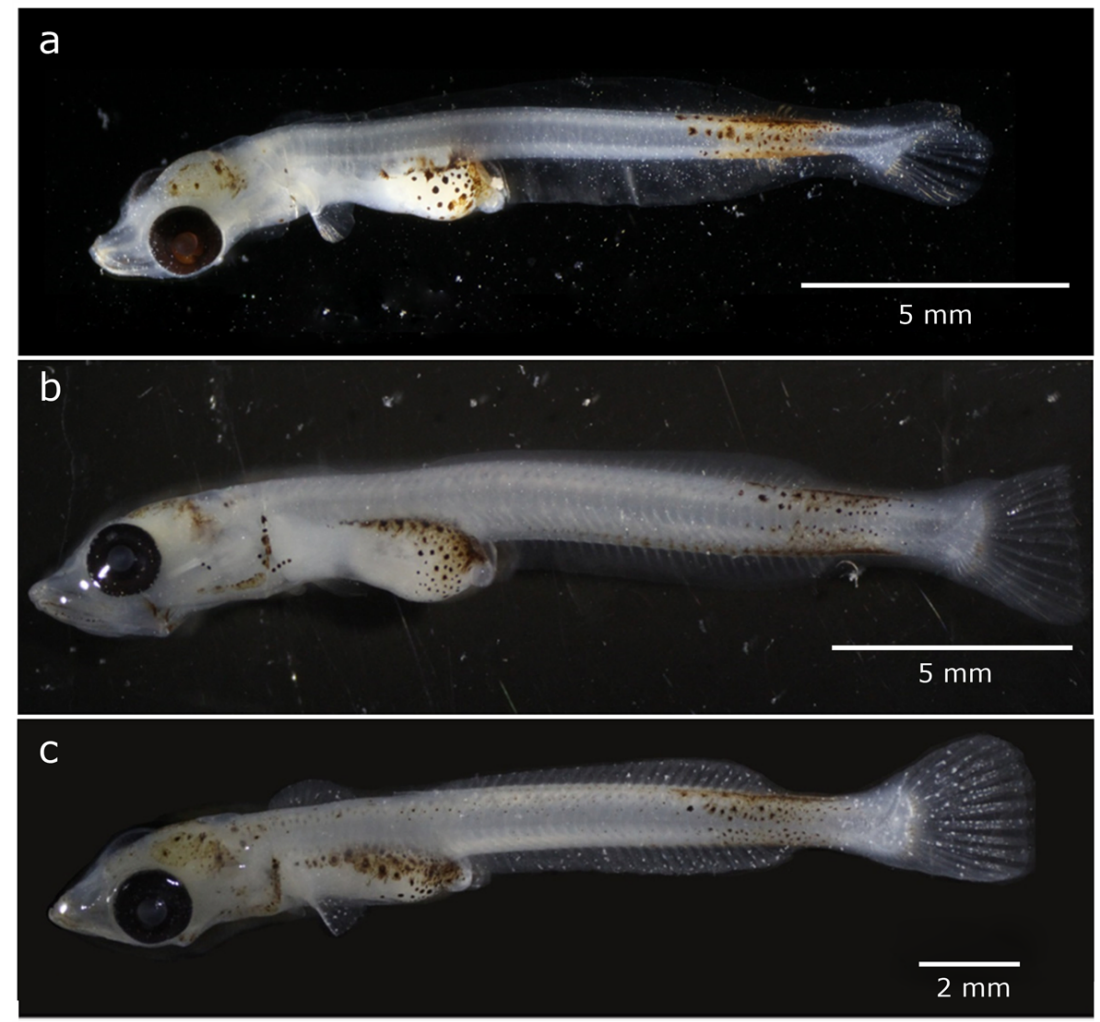

Figure 4. Lateral view of Dissostichus eleginoides (Patagonian toothfish) larvae. a) 26 days post-hatching, b) 44 days posthatching, c) $\mathbf{5 7}$ days post-hatching / Vista lateral de larvas de Dissostichus eleginoides (bacalao de profundidad). a) a 26 días de la eclosión. b) a 44 días de la eclosión, c) a 57 días de la eclosión 
The overall distribution pattern of melanophores in the most developed laboratory-reared embryos, which generally did not change in the early larval stages, closely resembled that reported by previous authors for wild embryos (Kellermann 1990, Evseenko et al. 1995). Interestingly, Kellerman (1990) noted a great similarity between the larval stages of $D$. eleginoides and Notothenia kempi, with the distribution pattern of melanophores acting as a discriminating factor. An additional differentiating characteristic between the two species is the pigment band on the posterior post-anal section of larvae, which, in D. eleginoides, develops dorsoventrally in the early larval stages before becoming discontinuous in the middle part during the late larval stages.

The laboratory-reared larvae presented between 44 and 48 myomeres. This differed from observations by Ciechomsky \& Weiss (1976) and Evseenko et al. (1995), who indicated the presence of 51-53 and 54-55 myomeres, respectively, in wild larvae. However, as previously reported by Evseenko et al. (1995), different myomere numbers can be observed in larvae collected from different sub-Antarctic localities or, as noted by Furtuño \& Olivar (1986), between wild and captive specimens.

Overall, the larval morphology observed in laboratory-reared D. eleginoides was very similar to that reported in previous studies (Ciechomsky \& Weiss 1976, Koubbi et al. 1990), especially regarding the distribution pattern of melanophores. However, a particularly notable difference was that wild larvae $14.5 \mathrm{~mm}$ TL in size still retained the yolk sac (Koubbi et al. 1990), whereas similarly-sized laboratory-reared larvae had already absorbed the yolk sac, had a functional mouth, and had started fin ray formation.

\section{ACKNOWLEDGMENTS}

The authors express the gratitude for the facilities provided by the Corporación de Educación La Araucana, Puerto Montt and researchers of FONDEF D06I1077 project, 'Development of Cultivation of Patagonian Toothfish (Dissostichus eleginoides)', which provided the biological material that allowed the development of this work. Especially to Ms. Ximena Moraga, responsible for the embryonic and larval cultivation of the species under study and Ms. Ashley VanCott the English translation and editing.

\section{LITERATURE CITED}

Arana P, M Arredondo \& V Venturini. 1994. Pesca del bacalao de profundidad (Dissostichus eleginoides), efectuada por la flota chilena en torno a la isla Georgia del Sur. Investigaciones Marinas 22: 67-84.

Ciechomsky J. 1981. Ictioplancton. En: Boltovskoy D (ed). Atlas del zooplancton del Atlántico sud occidental y métodos de trabajo con el zooplancton marino, pp. 829-860. INIDEP, Mar del Plata.

Ciechomsky J \& G Weiss. 1976. Desarrollo y distribución de postlarvas del robalo Eleginops maclovinus (Valenciennes, 1830) Dollo, 1904, de la merluza negra Dissostichus eleginoides Smitt, 1899 y de la notothenia Notothenia spp. Pisces, Nototheniidae. Physis (Sec. A) 35(91): 115-125.

Collins M, P Brickle, J Brown \& M Belchier. 2010. The Patagonian toothfish: biology, ecology and fishery. In: Lasser M (ed). Advance in Marine Biology 58: 227-300. Academic Press, Burlington.

Evseenko S, K Kock \& M Nevinsky. 1995. Early life history of the Patagonian toothfish, Dissostichus eleginoides Smitt, 1898 in the Atlantic sector of the Southern Ocean. Antarctic Science 7(3): 221-226.

Furtuño J \& M Olivar. 1986. Larvas de anguilliformes capturas en el atlántico sudoriental. Miscellania Zoológica 10: 223 231.

Kellermann A. 1990. Identification key and catalogue of larval Antarctic fishes. Berichte zur Polarforschung 67: 1-136.

Koubbi P, P Camus \& G Duhamel. 1990. Early life stages of Notothenioidei from the Kerguelen Islands. Cybium 14: 225 250.

Reyes A, R Kido \& C Moreno. 2012. Captura y mantención de Dissostichus eleginoides para conformar un plantel de reproductores. Latin American Journal of Aquatic Research 40(4): 1066-1071.

SUBPESCA. 2010. Cuota global de captura de bacalao de profundidad (Dissostichus eleginoides) en la unidad de pesquería, año 2011. Subsecretaria de Pesca y Acuicultura, Informe Técnico (R. Pesq.) 98: 1-25. 